\title{
Cool winters versus mild winters: effects on spring plankton in Lake Peipsi
}

\author{
Reet Laugaste, Juta Haberman, and Kätlin Blank ${ }^{\bowtie}$ \\ Centre for Limnology, Estonian University of Life Sciences, 61117 Rannu, Tartumaa, Estonia \\ $\bowtie$ Corresponding author, katlin.blank@ymail.com
}

Received 20 May 2010, revised 24 May 2010

\begin{abstract}
The influence of two winter periods with a different duration of the ice cover on Lake Peipsi (Estonia) on plankton and nutrient content was analysed. The winters of 2005 and 2006 were cold with ice duration of 140 days, whereas the winters of 2007 and 2008 were mild with about 50 and 15 days of ice duration, respectively. Total phosphorus (TP) concentration was lower, while silicon content and the nitrogen-phosphorus ratio (TN:TP) were markedly higher in the springs after the short winters of 2007 and 2008. The high Si concentration and TN:TP ratio persisted throughout the growing season of those years. Unicellular centric diatoms showed a sharp increase in April 2008, while the large filiform diatom Aulacoseira islandica dominated in the cool winters and after ice break-up. The high spring peak of diatoms was followed by their low biomass in summer. In May 2008, total zooplankton biomass, cladoceran biomass, and rotifer biomass were two times and that of copepods three times as high as in the Mays after the long-lasting ice cover. In the Junes after the mild winters the biomasses of total zooplankton and both crustacean groups (Cladocera, Copepoda) were about two times as high as the corresponding indicators for the Junes after the cool winters. The biomass of rotifers, on the contrary, was two times lower in the Junes after the warm winters because the numerous cold stenotherms Polyarthra dolichoptera and Synchaeta verrucosa had totally disappeared from zooplankton. The influence of ice duration on phytoplankton is most likely indirect, acting through nutrients, and on zooplankton direct, acting through water temperatures. The springs after warm winters related positively to zooplankters' mean weight, zooplankton-phytoplankton biomass ratio, and the timing of the clear water period.
\end{abstract}

Key words: Lake Peipsi, cool versus warm winter, zooplankton, phytoplankton, nutrients.

\section{INTRODUCTION}

Mean global air temperature has increased steadily in recent decades (Weyhenmeyer et al., 2008). Global average surface temperature of the Earth rose approximately by $0.6{ }^{\circ} \mathrm{C}$ in the 20th century. Regional climatic models for Sweden simulate increasing air temperatures over the following decades, especially temperatures in winter (Rummukainen et al., 2001). The warming trend in recent decades has led to an earlier ice break-up in lakes and to increased water temperature in many northern temperate lakes, particularly in spring (Gerten \& Adrian, 2000; Weyhenmeyer, 2001; Nõges, 2004; Adrian et al., 2006). Magnuson et al. (2000) 
reported a 6.3 days earlier ice break-up in lakes over the northern hemisphere in the past 100 years in response to the $1.2^{\circ} \mathrm{C}$ air temperature increase. The ice cover on lakes is not only a robust indicator of climate change and variation but it represents also a limnological response to climate change, which influences the ecology of the aquatic system: several studies showed that the ice cover has an impact on underwater light conditions (Leppäranta et al., 2003) and nutrient recycling (Livingstone, 1993), as well as on the production and biodiversity of phytoplankton (Phillips \& Fawley, 2002; Weyhenmeyer et al., 2008), and on the dynamics of zooplankton (Talling, 2003; Richardson, 2008; Blank et al., 2009). Other studies (Nõges, 2004; Wagner \& Benndorf, 2007; Blank et al., 2009) demonstrated that biological systems can exhibit responses to subtle climatic signals and could be sensitive indicators of climatic indices. Temperature-driven changes in interactions between populations are crucial to estimation of the impact of global warming on aquatic food webs (Wagner \& Benndorf, 2007). Climate warming is known to affect most winter and spring conditions (Sorvari et al., 2002; Weyhenmeyer et al., 2005). It is possible that winter conditions determine the 'inoculum' of species in spring and affect thus the succession pattern in spring and, possibly, also over the entire year (Adrian et al., 1999). The spring development of phyto- and zooplankton depends differently on physical conditions in early spring: phytoplankton depends on light (and on stratification in deep waters), while zooplankton depends on the availability of food and temperature (Sommer et al., 2007).

In the case of Lake Peipsi it is worth stressing that shallow freshwater ecosystems are particularly susceptible to externally imposed change, and are therefore likely to be the ecosystems facing considerable perturbation under scenarios of climate warming (McKee et al., 2002). According to Köhler \& Hoeg (2000), shallow lakes are more strongly influenced by stochastic meteorological events than deep lakes. In Lake Peipsi, the warm winters of 2007 and, particularly, of 2008 offer a possibility of comparing some spring parameters of water chemistry and plankton with those of the two previous moderately cold winters of 2005 and 2006. We presume that significant differences exist between these periods in the water nutrient content and plankton dynamics immediately after ice break-up and possibly also in the following months.

\section{STUDY SITE}

Lake Peipsi sensu lato (s.l.) is a large $\left(3555 \mathrm{~km}^{2}\right)$ and shallow (mean depth $7.1 \mathrm{~m}$ ) mainly unstratified lowland water body. Located on the Estonian-Russian border, Lake Peipsi is the largest international lake in Europe. Its water volume is $25 \mathrm{~km}^{3}$ at the long-term mean water level ( $30 \mathrm{~m}$ above sea level) and the mean residence time of water is about two years. The entire catchment area of $47800 \mathrm{~km}^{2}$ includes Estonian (34\%), Russian (58\%), and Latvian (8\%) territories. The catchment area is largely located in an agricultural region. The largest inflows are the Velikaya 
River in Russia and the Emajõgi River in Estonia. The Narva River, the only outflow of Lake Peipsi, falls into the Gulf of Finland. In the 1960s the lake was covered by ice for up to 6 months, but in recent decades the period of ice-cover has shortened to 3-4 months. In the winter of 2008, which is regarded as the warmest of the last 140 years (Jaagus, 2008), no permanent ice freeze-up occurred. The water is the warmest $\left(21-22^{\circ} \mathrm{C}\right.$ in open water) in July-August. The water is alkaline: the mean $\mathrm{pH}$ for the ice-free period is 8.36 (Milius \& Haldna, 2008).

The lake consists of three parts: the northern, the largest and deepest, is Lake Peipsi sensu stricto (s.s.; $2611 \mathrm{~km}^{2}$, mean depth $8.3 \mathrm{~m}$ ), and the southernmost part is Lake Pihkva $\left(708 \mathrm{~km}^{2}, 3.8 \mathrm{~m}\right.$ ), which is connected with Lake Peipsi s.s. by the river-like Lake Lämmijärv $\left(236 \mathrm{~km}^{2}, 2.5 \mathrm{~m}\right)$. On the basis of the OECD (1982) classification, Lake Peipsi s.s. is a eutrophic water body (total nitrogen (TN) 640, total phosphorus (TP) $50 \mathrm{~g} \mathrm{~m}^{-3}$ in summer for 2003-2008), while Lake Pihkva is hypertrophic at present (TN 1200 and TP $130 \mathrm{~g} \mathrm{~m}^{-3}$ ). Lake Peipsi s.s. was almost mesotrophic and Lake Pihkva eutrophic in the 1960s (Starast et al., 2001).

\section{MATERIALS AND METHODS}

Hydrobiological and hydrochemical samples were collected from March to June 2005-2008. Integrated samples of phyto- and zooplankton were obtained with the Van Dorn sampler by mixing the samples from the whole water column in a large vessel on board. The number of sampling sites was 6 in April-June and 13 in March when data for Lake Pihkva (located almost entirely in Russia) were available. The methods of collecting and treating samples are described in detail in Laugaste et al. (2001) and in Haberman (2001). Hydrochemical samples were analysed in Tartu Environmental Researchers Ltd, Estonia. Data on ice duration were obtained from the Estonian Institute of Meteorology and Hydrology. Samples of phytoand zooplankton were taken and water parameters and nutrient content were measured in parallel. Statistical conclusions and tests were made using a multiparametric regression model. Differences between the two periods were estimated with the help of parametrical functions (SAS Institute Inc., 1999). The program STATISTICA for Windows was used for drawing figures.

\section{RESULTS AND DISCUSSION}

\section{Ice duration and water temperatures in the months following ice break-up}

Climate research in Estonia has demonstrated a temperature rise of $1-1.7^{\circ} \mathrm{C}$ in the second half of the 20th century, with the most marked increase in spring (Jaagus, 2003) when the impact of temperature change on the biota is the most significant. The impact on aquatic systems is expressed by an earlier ice breakup, lengthening of the vegetation period, and increase in the productivity of water 
bodies (Irigoien et al., 2000). Shatwell et al. (2008) defined the start of spring as the time when water temperature reaches $3^{\circ} \mathrm{C}$, which corresponds to the time of ice thaw, and the end of spring as the time of the clear-water phase. For Lake Peipsi the start of spring is considered to occur at a water temperature of $4{ }^{\circ} \mathrm{C}$ (Jaani, 2001).

According to earlier data, the ice cover on Lake Peipsi lasts up to 6 months and attains a thickness of more than $1 \mathrm{~m}$ in some cases (Jaani, 2001). In recent decades, short and mild winters were frequent and lasted less than two months, as was the case in 2007. Moreover, a permanent ice cover was almost lacking on the lake in the winter of 2008. The two mild winters, 2007 and 2008, provided us with a 'natural experiment' and allowed drawing a parallel with the winter and spring conditions in the two earlier years with the so-called 'normal' winters when the ice duration was more than four months (Table 1). Obviously, the time of ice break-up affects water temperatures most strongly in April. However, also in May an effect of the time of ice break-up and severity of winter on water temperature could be observed. An earlier analysis of a 12-year data set (19972008; Blank et al., 2009) also showed that water temperatures in May are positively correlated with those in April $(r=0.68, p<0.001)$. As a rule, water and air temperatures in June behaved independently of winter conditions. The sum of water temperatures of April and May is the key factor to prompt the growth of phyto- and zooplankton and hence the subsequent dynamics of these groups. Another significant factor is the impact of the severity of winter on the concentration of nutrients, which affects particularly the composition and biomass of phytoplankton in the following months.

\section{Influence of winter on nutrients in the following months}

Long-term analyses of the physical and biological characteristics of freshwater ecosystems in Northern Europe have shown that climate change affects winter concentrations of nitrate nitrogen and dissolved reactive phosphorus (George et al., 2004) as well as the timing of the events of the seasonal succession of

Table 1. Severity of winter, ice duration, and water temperatures $\left({ }^{\circ} \mathrm{C}\right)$ in spring in the studied years

\begin{tabular}{l|c|c|c|c}
\hline & 2005 & 2006 & 2007 & 2008 \\
\hline $\begin{array}{l}\text { Ice duration, days } \\
\text { Sum of negative }\end{array} \quad 144$ & 138 & 49 & 15 \\
$\quad$ air temperatures & 620 & 801 & 463 & 268 \\
$\begin{array}{l}\text { Sum of water temperatures } \\
\quad \text { April }\end{array}$ & 92 & 109 & 189 & 165 \\
$\quad$ May & 351 & 416 & 389 & 409 \\
$\quad$ April + May & 443 & 525 & 579 & 574 \\
$\quad$ June & 518 & 574 & 583 & 506
\end{tabular}


phytoplankton and zooplankton (Weyhenmeyer, 2001; Gerten \& Adrian, 2002; Romare et al., 2005; Adrian et al., 2006; Richardson, 2008; Shatwell et al., 2008). The water chemistry of Lake Peipsi revealed some differences between the two observation periods. The concentration of total phosphorus (TP) was significantly lower after the warm winters $(p=0.007)$ while the concentration of total nitrogen (TN) was only slightly (not significantly) higher in that period. As a consequence, the TN:TP ratio was significantly higher for the spring months after the warm winters of 2007 and 2008 than after the cold winters (Fig. 1).

Our earlier observations since 1997 revealed increased TP concentrations in spring when the ice cover had lasted three months or longer (Blank et al., 2009). This can be explained by oxygen depletion in the bottom layer and an increased release of $P$ from the sediments in the case of a longer ice cover in late winter. In very shallow lakes, the action of the wind and waves is known to influence the transfer of nutrients from bottom sediments in the ice-free period, and large internal phosphorus loading may occur when wind-induced resuspension reaches deeper, anoxic sediments with a high $\mathrm{P}$ concentration in pore water (Nõges \& Kisand, 1999). These authors noted that the daily release of soluble reactive phosphorus during the storm exceeds the annual external P load to Lake Võrtsjärv (mean depth $2.8 \mathrm{~m}$ ). This effect is not observed in Lake Peipsi with a mean depth of $8.3 \mathrm{~m}$ in the largest part. This lake is unique among large lakes as it differs both from deep stratified lakes and very shallow lakes.

Differences between the two periods were also observed in the mineral forms of nutrients: the concentration of nitrate nitrogen $\left(\mathrm{NO}_{3} \mathrm{~N}\right)$ was higher $(p=0.021)$ and those of ammonia $\left(\mathrm{NH}_{4} \mathrm{~N}\right)$ and phosphates $\left(\mathrm{PO}_{4} \mathrm{P}\right)$ were lower after the mild winters ( $p=0.012$ and 0.015, respectively). Our data since 1997 (Blank et al., 2009) also show that the concentration of nitrogen, particularly that of nitrates, is inversely

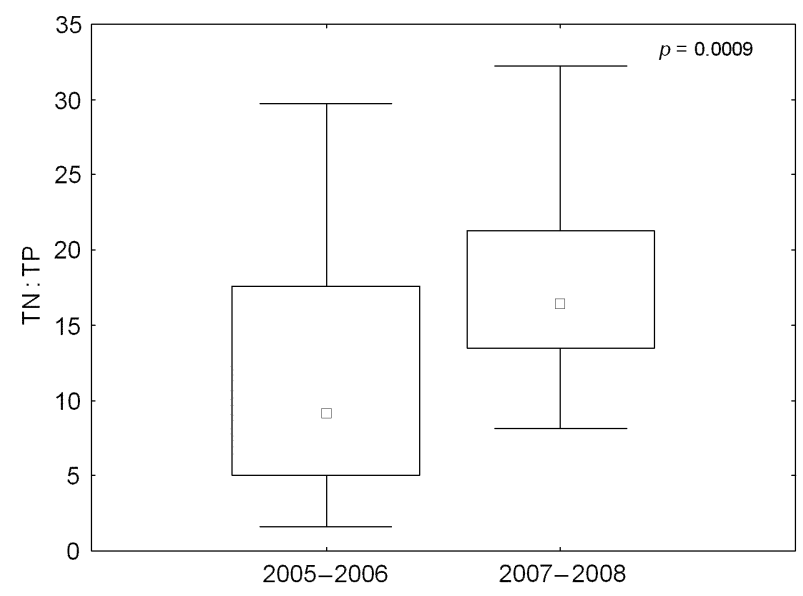

Fig. 1. Total nitrogen to total phosphorus ratio in spring (April-June) of the two observation periods. 
related to ice duration $\left(r^{2}=0.39, p=0.001\right)$ and the sum of water temperatures up to sampling in May $\left(r^{2}=0.36, p=0.018\right)$. A significant difference between the two periods under study was found in the silicon concentration, which was higher after the warm winters $(p=0.0004)$. Unlike our data, Weyhenmeyer et al. (2008) noted lower values of nitrate $\mathrm{N}$ and $\mathrm{Si}$ in Lake Vänern in ice-free winters and higher values of those elements in winters with an ice cover. This was connected with phytoplankton growth, as the chlorophyll $a$ content and phytoplankton biomass were significantly higher in the studied ice-free winters. No differences between the two observation periods were found in the present study in chemical oxygen demand $\left(\mathrm{COD}_{\mathrm{Cr}}\right)$ and the concentration of iron: both showed markedly higher values after the cool winters according to our data since 1997.

\section{Phytoplankton}

Spring plankton communities of temperate lakes are characterized by a domination of fast-growing species (diatoms, cryptophytes), which are adapted to the prevailing steep temporal gradients of temperature and light, resulting in immediate and likely synchronous phenology shifts towards climate warming. In April-May 2005 and 2006, Aulacoseira islandica (O. Müller) Simonsen prevailed in L. Peipsi s.s., and Cyclotella spp. and Aulacoseira ambigua (Grun. in Van Heurck) Simonsen prevailed in L. Lämmijärv. In April-May 2007, Stephanodiscus neoastraea Håk. et Hickel appeared in the northern part. In March 2008, most sampling points were ice-free and dominated by the large $S$. neoastraea. In both mild years, the biomass of diatoms was extraordinarily high in the winter season as well as after ice break-up in April (Fig. 2). Also Köhler \& Hoeg (2000) stressed the positive effect of a mild winter and short ice cover for centric diatoms.

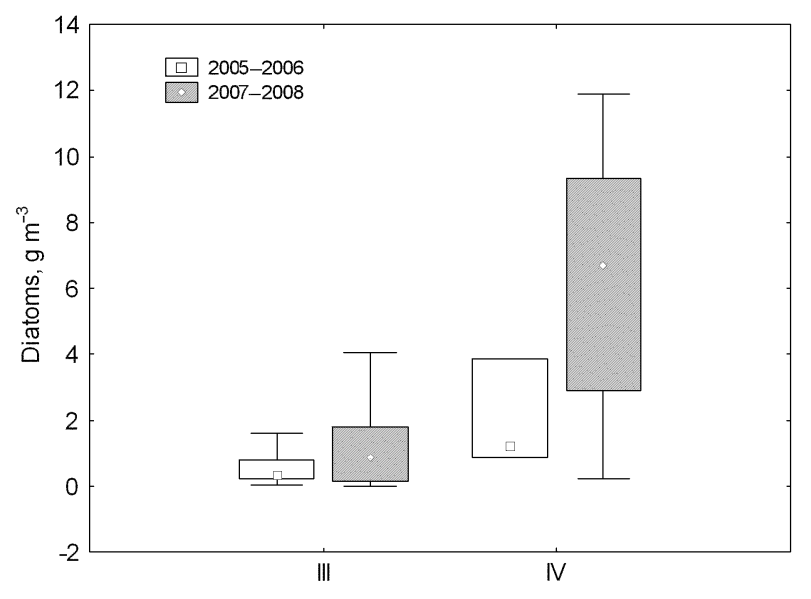

Fig. 2. Biomass of diatoms in March and April in the two observation periods. 
In May 2007 and 2008, the total biomass of phytoplankton increased after earlier ice break-up, and the higher biomass of diatoms after the warm winters was in accordance with higher concentrations of silicon $(r=0.45, p=0.002)$. Also the growth of other algal groups (cyanobacteria, chlorophytes, and cryptophytes) occurred earlier in those years compared to the spring months of 2005 and 2006. Adrian et al. (1999) analysed the timing of maxima of different phytoplankton and zooplankton groups in a shallow lake and found that the plankton groups that appeared first in seasonal succession reached their maximum abundance earlier after mild and average winters than after cold winters. In Lake Peipsi, the longer growing season and the higher $\mathrm{N}: \mathrm{P}$ ratio after the mild winters had an effect on the phytoplankton composition in the following months. Contrary to the recognized opinion about the positive effect of a long growing season on water bloom (Weyhenmeyer at al., 2002), the summer water bloom in Lake Peipsi was more modest in 2007 and 2008 than in 2005 and 2006 (Fig. 3). Also, the relatively low air and water temperatures in the summer months, particularly in 2008, probably played a significant role. The high N:P ratio as well as the high silicon concentration after the mild winters can explain the high spring peak of diatoms and their modest biomass in summer due to exhausted silicon resources. On the contrary, the lower spring peak of diatoms after the severe winters is related to their higher biomass in summer (Fig. 4). Sorvari et al. (2002) noted a close connection between spring temperatures and the composition of diatom plankton in lakes of Finnish Lapland.

An earlier ice break-up brings about an increase in the species abundance: in Lake Peipsi it was clearly higher in May $(p=0.031)$ and the following growing season of 2007 and 2008 than after the cold winters $(p<0.0001)$. The species number of cyanobacteria and chlorophytes, but not that of diatoms, was influenced by the earlier ice break-up.

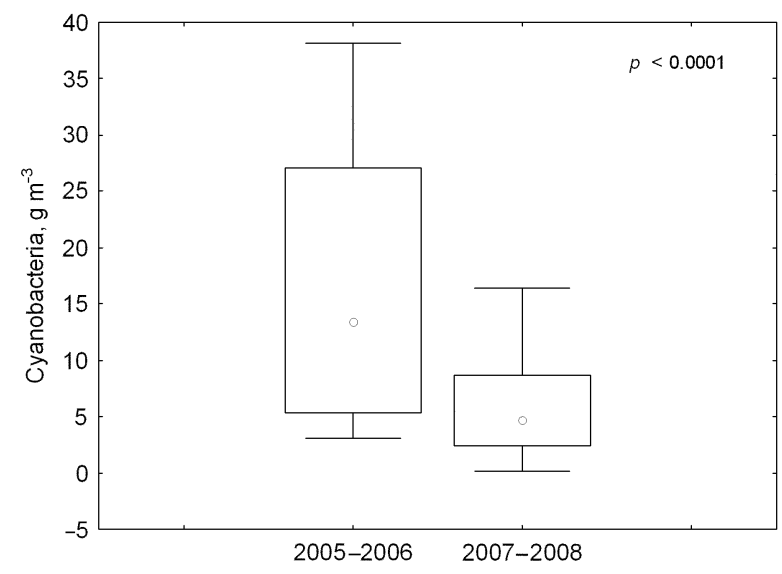

Fig. 3. Biomass of cyanobacteria in summer (July-August) in the years with severe and mild winters. 


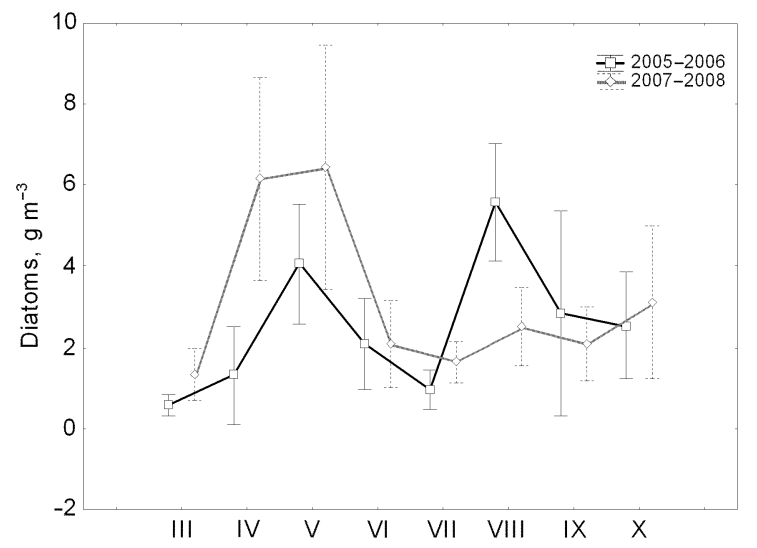

Fig. 4. Seasonal dynamics of diatoms in the two observation periods.

Recent studies have shown that changes in the temperature regime and in the timing of lake ice break-up are reflected in the increasing trend of the North Atlantic Oscillation (NAO) index (Livingstone, 2000; Nõges, 2004), which characterizes the variability of air pressure differences between Iceland and the Azores (Hurrell et al., 2001). Weyhenmeyer et al. (2002) demonstrated that in 1999, with the highest value of the NAO winter (NAOw) index, the biomass of diatoms in May was low, indicating that diatoms disappeared from the water column earlier than usual. The timing of the phytoplankton spring peak is strongly dependent on the length of the winter ice cover (Shatwell et al., 2008). The frequency of warm and short winters is largely affected by the increasing trend of the NAO index. On the basis of our data from 1970 to 2009, the NAOw index (December, January, February) was correlated negatively with water level and positively with water temperatures in the following growing season (average for May-October) in Lake Peipsi s.l. $(r=-0.52, p=0.001 ; r=0.329, p=0.041$, respectively). A positive correlation between the NAOw index and phytoplankton biomass (data for 1970-2009) was observed for the summer months in the shallow Lake Pihkva $(r=0.37, p=0.029)$ but not in the deeper Lake Peipsi s.s. Also Nõges (2004) confirmed positive correlations between the NAOw index and water temperatures in some following months (April, July, and September) and an inverse relationship between the phytoplankton biomass and water level in summer in the shallow Lake Võrtsjärv. Evidently, very shallow lakes are more responsive to the variability of the NAO. Concordance between the low water level and high phytoplankton biomass in Lake Peipsi was described in an earlier study (Laugaste et al., 2001). This is consistent with the mean values of the NAO index for the year, which had a positive correlation with water temperatures of the growing season $(r=0.28$, $p=0.046)$ and with the phytoplankton biomass in Lake Pihkva $(r=0.38, p=0.027)$, and a negative correlation with the water level of the growing season $(r=-0.48$, $p=0.011$ ). However, the NAO spring index (March, April, May), which was 
strongly positively correlated with the sum of water temperatures in May in the whole Lake Peipsi $(r=0.748, p=0.008)$, revealed no correlation with the spring phytoplankton biomass.

\section{Zooplankton}

Typically, a spring maximum of phytoplankton, dominated by diatoms, is accompanied or followed by a maximum of copepods and then by a maximum of cladocerans dominated by the Daphnia hyalina galeata complex (Talling, 2003). As water temperature is considered to be one of the most important factors influencing zooplankton abundances in spring in temperate lakes (Swadling et al., 2000; Chen \& Folt, 2002; Shatwell et al., 2008; Blank et al., 2009), climatic factors such as an increase in winter/spring air temperature affect the timing of zooplankton spring development (Weyhenmeyer et al., 1999; Mehner, 2000; Gerten \& Adrian, 2002; Romare et al., 2005; Wagner \& Benndorf, 2007; Richardson, 2008).

It is known that rotifers as well as copepods (mainly juvenile forms) prevail in winter zooplankton (Ventelä et al., 1998; Virro et al., 2009), but dominants can differ markedly between different years (Sarvala et al., 1998). In Lake Peipsi the most common stenothermic winter rotifers were Synchaeta verrucosa (Nipkow) and Polyarthra dolichoptera (Idelson); among eurythermic species, the most frequent were Keratella cochlearis (Gosse) and K. quadrata (Müller). Like in winter, in May zooplankton was also dominated by rotifers and juvenile forms of copepods (genus Mesocyclops, Cyclops kolensis Lilljeborg). In May the average water temperature $\left(\sim 10^{\circ} \mathrm{C}\right.$ in the study years, long-term average $8^{\circ} \mathrm{C}$ for Lake Peipsi s.s. and $11^{\circ} \mathrm{C}$ for Lake Lämmijärv) does not favour the development of thermophilic cladocerans. The share of cladocerans was about $2 \%$ in the abundance of zooplankton and $7 \%$ in their biomass. Cladoceran biomass was built up of species from the genus Bosmina ( $B$. berolinensis Imhof, $B$. gibbera Schoedler, B. longirostris (Müller), B. thersites (Poppe)); the occurrence of Daphnia spp. was very low. Most cyclopoid copepod species undergo diapause in the sediment in the late copepod stage in winter, which is also the case in Lake Peipsi as adult copepods are absent from the pelagic zone in winter and early spring. A similar situation was noted for the early spring copepod population in Lake Müggelsee, Germany (Adrian et al., 2006). The occurrence of adult $C$. kolensis is quite rare in Lake Peipsi. A declining trend of C. kolensis biomass was detected in the winter zooplankton of Lake Peipsi since the 1980s (Haberman, 2001). It can be explained by the strong predation pressure by fish (Ibneeva, 1983), by the high trophic state of the lake (Sikorowa et al., 1975; Haberman, 2001), and by changes in the structure of zooplankton due to warm winters (Adrian \& Deneke, 1996). In the shallow eutrophic lakes Nero and Seliger in Russia, C. kolensis is not numerous either (Rivier, 1996).

The warm springs (2007 and 2008) differed from the cold springs in that the winter thermophobic rotifers $P$. dolichoptera and $S$. verrucosa, whose large numbers 
are frequent in cold May, never dominated in the zooplankton abundance. Another evident difference was domination of some cladoceran species, mainly $B$. berolinensis, in the zooplankton biomass in the warm springs, which does not happen when temperatures are lower in May. Climate impacts on the distribution and phenology of the biota may act not only directly through individual physiology but also indirectly through species interactions (Berger et al., 2007). Climate warming is predicted to induce a shift not only in the timing of the onset of the growth of phytoplankton but also in that of Daphnia populations (Scheffer et al., 2001). However, these shifts are caused by different mechanisms: in the case of phytoplankton, it is the earlier transition from strong to weak vertical mixing that causes its shift; in the case of Daphnia, it is the increase in water temperature (Straile, 2000). This difference in the responsible mechanisms makes it unlikely that climate warming will result in the same temporal shift in the onset of the growth of both phytoplankton and Daphnia populations. Before daphnids become dominant other zooplankton taxa, such as ciliates in the case of Lake Constance (Weisse et al., 1990) and the genus Bosmina and copepod juveniles in the case of Lake Peipsi, are responsible for phytoplankton loss. As the rates of grazing and population growth of these zooplankton taxa differ from those of daphnids, a shift in the timing of phytoplankton growth will have important consequences for the structure of the zooplankton community (Peeters et al., 2007).

Despite only a slight difference in the water temperatures on the sampling day between the cool (2005 and 2006) and the warm (2007 and 2008) May, zooplankton biomass was almost two times higher in the warm May; the group influenced most by water temperature was the copepods (Table 2). In May 2008 the biomass of zooplankton, cladocerans, and rotifers was two times and that of copepods three times as high as in May 2005 and 2006 after a long-lasting ice cover. Identification of changes in the dynamics of cyclopoid copepods is quite problematic because of the complexity of their lifestyle. However, warming in late spring had a strong impact on the population development of Thermocyclops oithonoides in Müggelsee, and high spring temperature led to the early emergence of copepodites and, subsequently, to their early maturity (Gerten \& Adrian, 2002).

Zooplankton biomass in spring was positively correlated with the sum of water temperatures from ice break-up to the sampling date $(r=0.5, p<0.001)$ and was larger after the warm winters. At the same time, the abundance of zooplankton decreased in spring (June) after the warm winters due to the rapid decline in rotifers, which formed the bulk of plankton in winter and immediately after ice break-up (Fig. 5). The increase in the zooplankton biomass after the warm winters was primarily induced by the steady growth of cladocerans $(p=0.004)$.

In Lake Peipsi, intense development of cladocerans, especially the genus Daphnia (D. cucullata Sars, D. galeata Sars, D. cristata Sars), starts in June at water temperatures of $15-16^{\circ} \mathrm{C}$ (Haberman et al., 2008). In June, the share of 


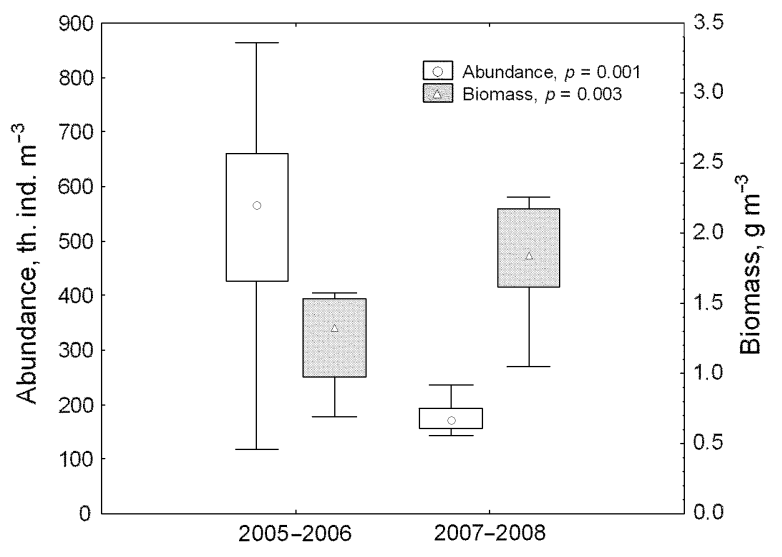

Fig. 5. Zooplankton abundance and biomass in June of the two observation periods.

cladocerans in the zooplankton abundance and biomass was $11 \%$ and $42 \%$ in the Junes after the cold winters and $24 \%$ and $64 \%$ in the Junes after the warm winters, respectively. In June 2007, the biomass of the genus Daphnia was about four times as large and in June 2008 up to ten times as large as in June 2005 and 2006. Also, the biomass of the genus Bosmina was markedly larger in spring in the second observation period $(p=0.02)$. Our observations in 1997-2008 (Blank et al., 2009) showed that the share of cladocerans in the zooplankton biomass and abundance had a significant positive correlation with water temperatures in spring $(r=0.7, p<0.001)$. The biomass of zooplankton was mainly formed of D. cucullata (up to $75 \%$ ) and D. galeata (up to $55 \%$ ); at the same time, the share of the filterfeeding Eudiaptomus gracilis (Sars) was also remarkable (up to 44\%). Obviously, higher water temperature supported the development of D. cucullata, which is one of the most thermophilous cladocerans in Lake Peipsi. It usually appears in June (average water temperature $17.6^{\circ} \mathrm{C}$ ), disappears in September-October, and is found at water temperatures of $7.8-23.4^{\circ} \mathrm{C}$ (Haberman, 2001). Mild winters favour an early build-up of Daphnia populations, both directly through increased surface temperatures and indirectly by enhancing algal production (Berger et al., 2007). The data by Wagner \& Benndorf (2007) suggest that even a slight warming by $1.7^{\circ} \mathrm{C}$ during a short, but critical seasonal period, resulting in the coincidence of other factors affecting keystone species, such as Daphnia, may induce changes in whole lake food webs and thus alter the entire ecosystem. In the Junes after the warm winters the biomass of total zooplankton and both crustacean groups (Cladocera, Copepoda) was about two times as large as the corresponding indicator for the Junes after the cool winters (Table 3). Inversely, the biomass of rotifers was two times as small as in the Junes after the warm winters because the numerous cold stenotherms $P$. dolichoptera and $S$. verrucosa had completely disappeared from zooplankton owing to the unsuitable water temperature, while the summer complex of rotifers had not yet completely formed. It is known that 


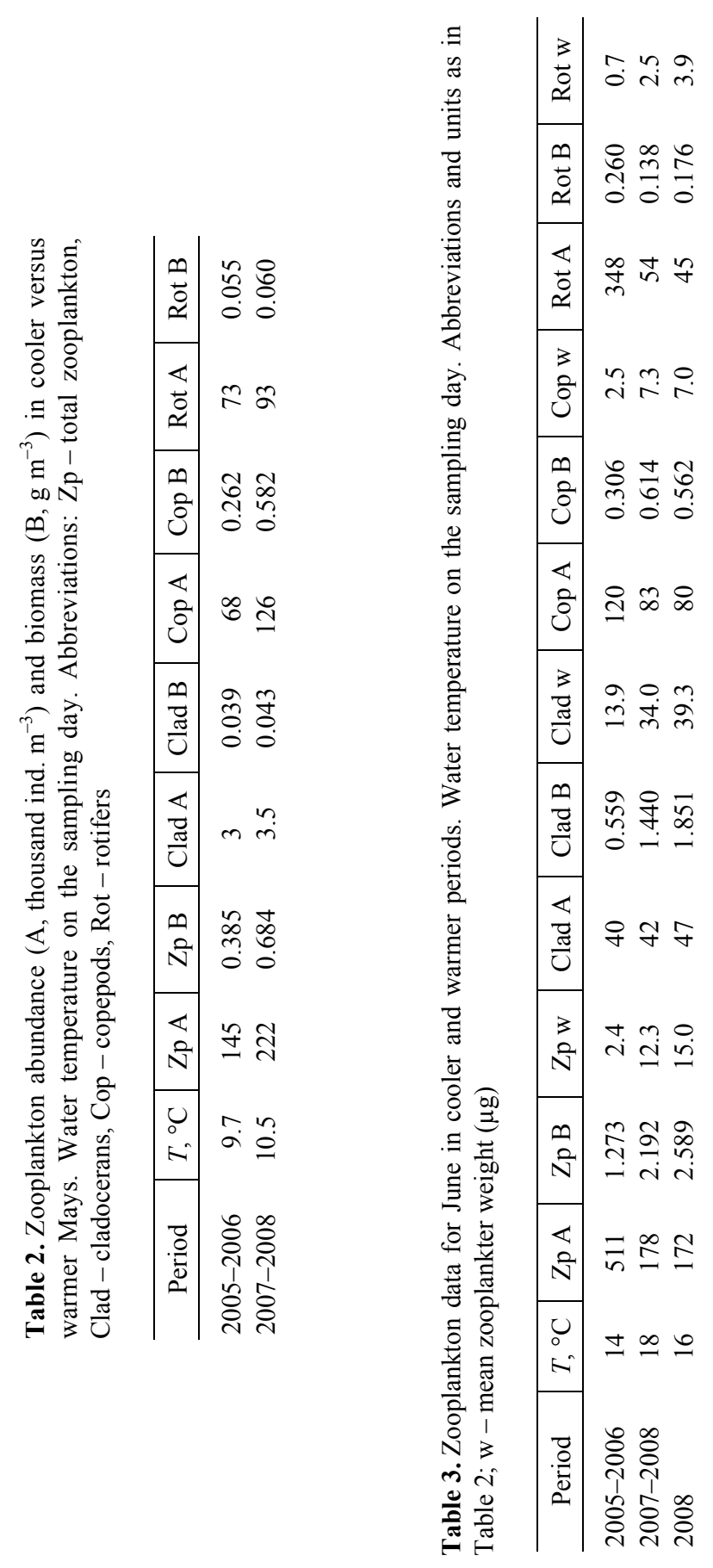


also in the other large and shallow Estonian lake, Võrtsjärv, connected with Lake Peipsi, both $P$. dolichoptera and $S$. verrucosa are represented in spring plankton only at water temperatures up to $14^{\circ} \mathrm{C}$ (Haberman, 1995).

The mean weight of a zooplankter and individuals of different zooplankton groups reflect well the weight composition and hence the grazing capacity of zooplankton. In the Junes after the warm winters the mean weight increased 5 times per zooplankter, 2.4 times per cladoceran, almost 3 times per copepod, and 3.6 times per rotifer. The greater mean weight of rotifers $(p=0.006)$ can be explained by the frequent appearance of the large-bodied Asplanchna priodonta Gosse in the plankton of that period. Neglecting the presence of $A$. priodonta, the mean weight of a rotifer individual in the Junes after the warm winters would be lower than the mean weight of a rotifer in the Junes after the cool winters as the disappeared S. verrucosa is larger than K. cochlearis and especially K. tecta Gosse, which dominated in the abundance of zooplankton in June. As the mean zooplankter weight depends directly on average monthly water temperatures (Haberman \& Künnap, 2002), it was higher after the warm winters (Fig. 6). The mean weight of copepods was higher in the second observation period $(p=0.013)$ due to the increased abundance of the large-bodied Eudiaptomus gracilis. Copepods spend the winter diapausing on sediment as copepodites of the fifth stage and move up into the water layer under favourable temperature and light conditions. Soon they become mature and begin to reproduce so that different juvenile stages are numerous in the water at that time. After ice break-up in April-May the amount of hatched nauplii as well as copepodites increases and their share in the total zooplankton biomass increases as well. The increase was steeper after the warm winters; the development of nauplii into copepodites was more rapid, and in the Junes after the warm winters the decrease in the biomass of nauplii, as well as the increase in the biomass of copepodites, was steeper than after the cool winters (Fig. 7).

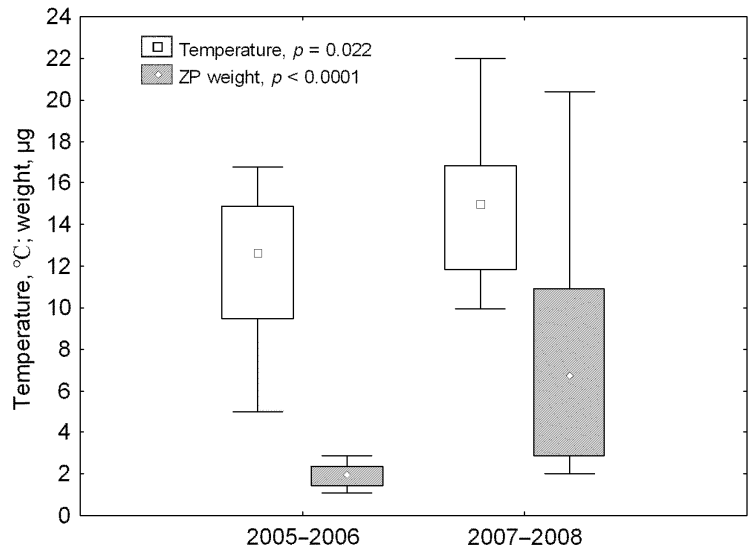

Fig. 6. Mean zooplankter weight and mean monthly water temperature in May-June. 


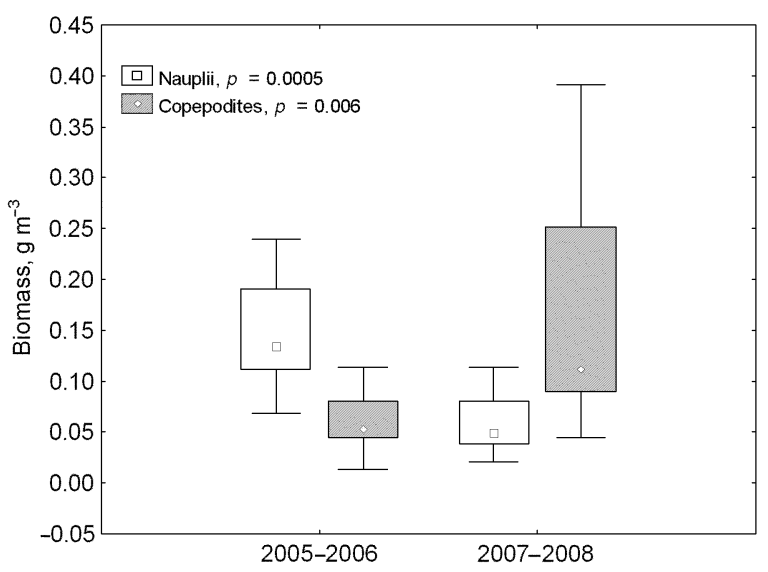

Fig. 7. Biomass of nauplii and copepodites in June of the two observation periods.

\section{Zooplankton-phytoplankton biomass ratio $\left(\mathrm{B}_{\mathrm{Zp}} / \mathrm{B}_{\mathrm{Phyt}}\right)$ and the clear- water period}

The ratio $\mathrm{B}_{\mathrm{Zp}} / \mathrm{B}_{\text {Phyt }}$ is a well-known indicator of the state of a water body: it is higher in the case of a lower trophic state of the lake (Andronikova, 1996; Haberman \& Laugaste, 2003; Jeppesen et al., 2005). This ratio reflects largely the type (effectiveness) of the food web and hence the character of the ecosystem. Indirectly, it characterizes the dominating groups in plankton, feeding relationships between phyto- and zooplankton, and the pressure of fish on zooplankton. The seasonal variability of the ratio depends on the dynamics of both plankton groups. For Lake Peipsi quite a marked increase in the ratio (up to 1) was observed in May while the maximum values (up to 2 ) occurred in June. In these months, $\mathrm{B}_{\mathrm{Zp}} / \mathrm{B}_{\text {Phyt }}$ showed the widest yearly range of fluctuations caused by differences in the melting time of the ice cover and hence in the timing of the phytoplankton spring peak in different years. This ratio was markedly higher after the warm winters (Fig. 8a), which is connected with the more numerous appearance of thermophilous and large-bodied cladocerans. The highest ratio for June reflects a drop in phytoplankton biomass after its spring peak and increasing grazing of zooplankton. It is worth noting that small-celled algae (unicellular centric diatoms and cryptophytes), serving as suitable food for zooplankton, and large-bodied zooplankters (mainly powerful grazers from the genus Daphnia) were prevailing in June. Consequently, phytoplankton was most likely controlled by top-down (zooplankton) forces. The mean ratio of 0.62 for June (1997-2008) in Lake Peipsi s.s. (Blank et al., 2010) allows us to suppose that an efficient algal food chain may occur then, while in the other months an inefficient microbial food chain is prevalent. The values of $\mathrm{B}_{\mathrm{Zp}} / \mathrm{B}_{\text {Phyt }}$ suggest that the impact of herbivory (top-down pressure on phytoplankton) is negligible and the bulk of primary production remains uneaten, which is probable 


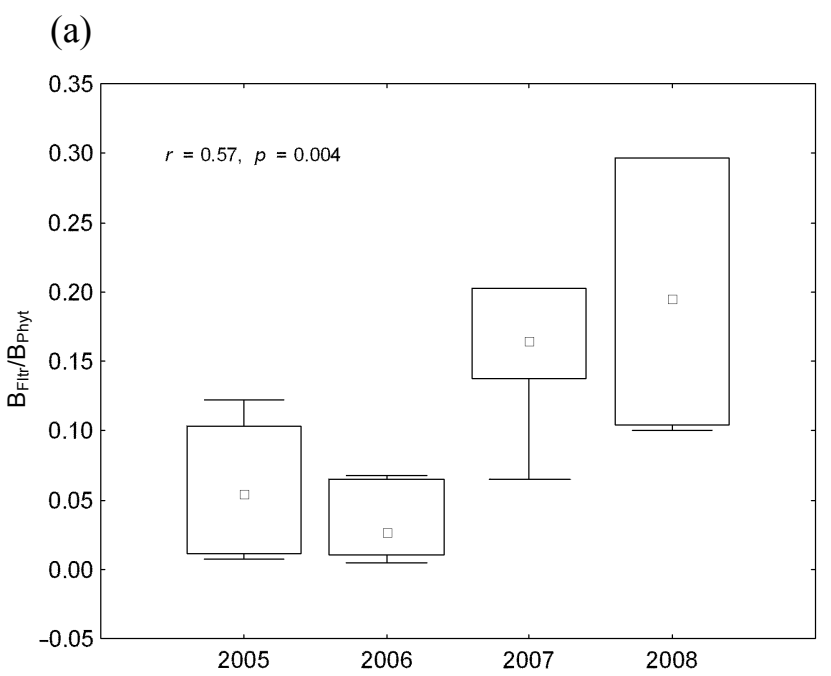

(b)

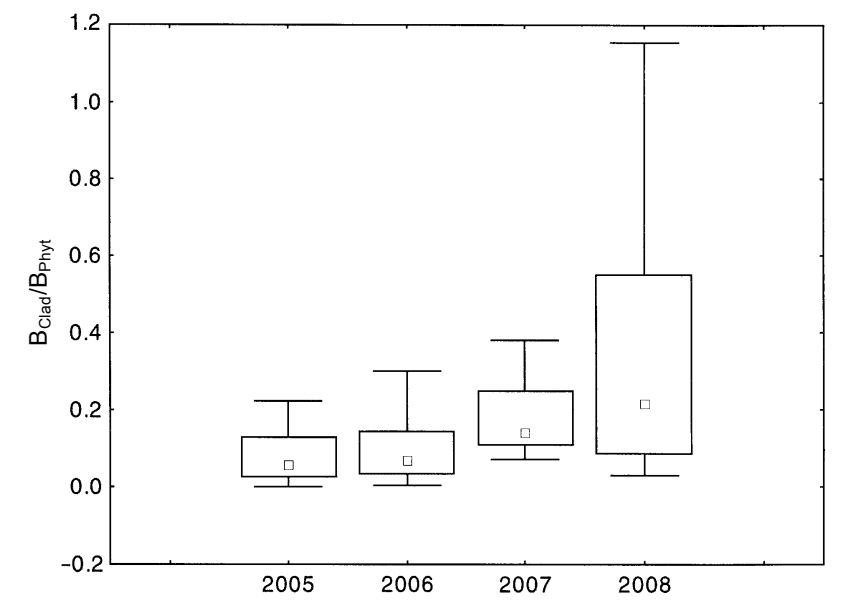

Fig. 8. Zooplankton to phytoplankton biomass ratio in May (a) and average ratio of May-October (b) in the studied years.

for the eutrophic Lake Peipsi s.s. and evident for the hypertrophic Lake Pihkva. The almost ice-free winter of 2008 affected this ratio positively in the following growing season (Fig. 8b), reflecting the decrease in the trophic state at that time. Clearly, the influence of the cool summer of that year must not be neglected.

Besides $\mathrm{B}_{\mathrm{Zp}} / \mathrm{B}_{\text {Phyt }}$, the ratios of cladocerans to phytoplankton biomass $\left(\mathrm{B}_{\text {Clad }} / \mathrm{B}_{\text {Phyt }}\right)$ and all filtrators to phytoplankton biomass $\left(\mathrm{B}_{\text {Filtr }} / \mathrm{B}_{\text {Phyt }}\right)$ characterize well feeding relationships and timing of the clear-water phase in spring. These ratios are influenced by temperatures, which are higher in warm springs. According to 
Matveev \& Matveeva (1997), the ratio $\mathrm{B}_{\text {Clad }} / \mathrm{B}_{\text {Phyt }}$ above 0.1 indicates a significant effect of cladoceran grazing on phytoplankton. In Lake Peipsi, the effect exerted on phytoplankton by filtrative copepods (Eudiaptomus and copepodites) in May and by cladocerans in June (mainly Bosmina, later Daphnia) was more evident after the mild winters (Fig. 9a, b).

In temperate lakes, the most conspicuous events during the seasonal succession of the plankton community are phytoplankton spring bloom and the subsequent clear-water phase, a period of low phytoplankton biomass caused by the intensive grazing of the growing population of crustacean zooplankton (Berger et al., 2007). In Central European lakes, the timing of the clear-water phase is linked to large-

\section{(a)}

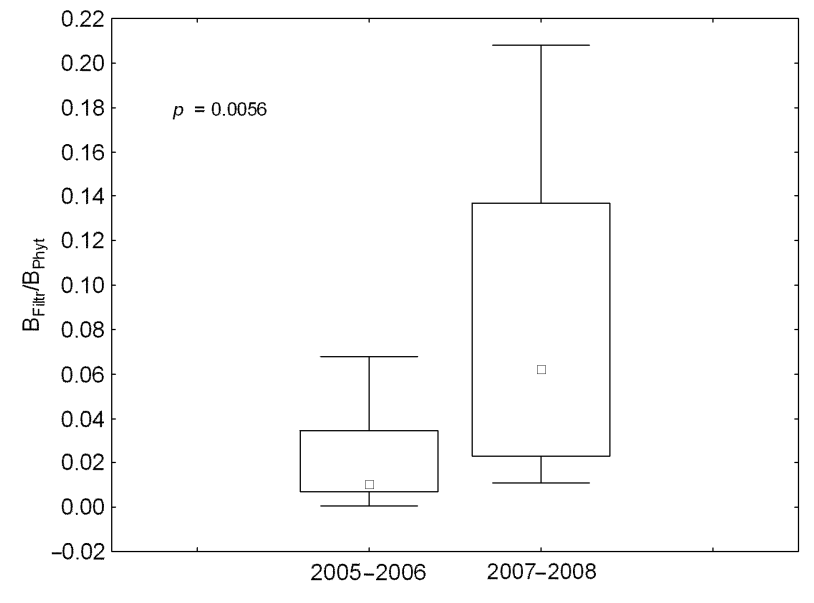

(b)

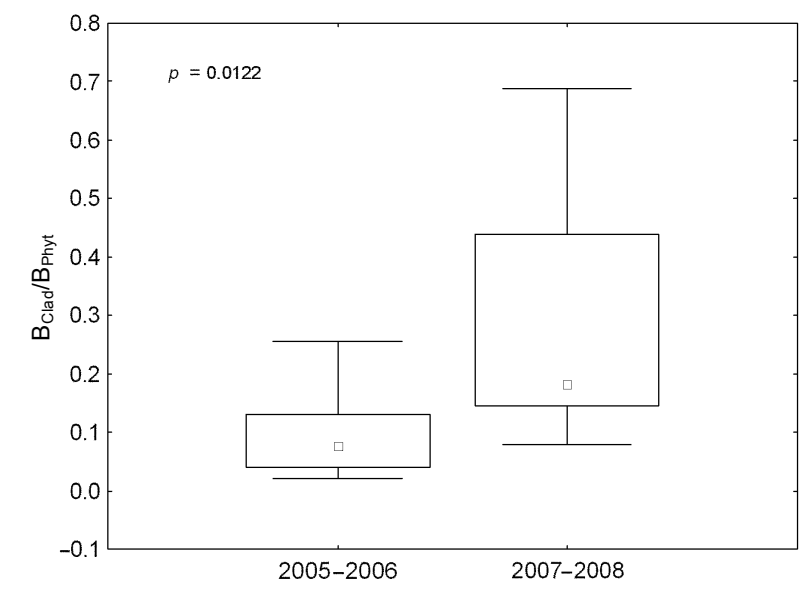

Fig. 9. Biomass ratios of filtrative zooplankton to phytoplankton in May (a) and cladocerans to phytoplankton in June (b). 
scale climatic forcing, with warmer winters being followed by an earlier onset of the clear-water phase (Straile, 2000, 2002; Scheffer et al., 2001). Wagner \& Benndorf (2007) showed that the clear-water phase starts 5.8 days earlier per degree of warming after warmer winters compared to colder ones. According to our data for Lake Peipsi from 1997-2008 (Blank et al., 2009), Secchi disc values in May had negative correlations with ice duration $(r=-0.62, p<0.001)$. A clearwater period in June coincided with belated ice break-up (in late April or early May). The biomass of total phytoplankton, cyanobacteria, diatoms, and chlorophytes revealed quite strong negative correlations with Secchi values in May and June $(p \leq 0.001)$, the strongest being the correlation between cyanobacteria and Secchi values in June $(r=-0.82)$. The zooplankton groups were differently related to transparency: rotifers showed positive correlations for May and June, and copepods as well as the genus Daphnia showed negative correlations for June. Zooplankton spring growth follows the phytoplankton spring bloom; after a few weeks of zooplankton increase, its grazing rates exceed phytoplankton production, leading to its minimum in late spring-early summer, i.e. the clear-water phase (Sommer et al., 2007).

In conclusion, we can say that the effect of the severity of winter on phytoplankton in the months following ice break-up occurs quite indirectly, possibly through relationships with nutrients. Zooplankton is most likely directly affected by the dynamics of water temperatures. The results of an experiment presented by the nature allowed us to conclude that a warm winter and an early ice break-up have a significant effect on the chemical composition of water and on spring phyto- and zooplankton, as well as, partly, on the whole subsequent growing season.

\section{ACKNOWLEDGEMENTS}

The research was supported through targeted financing of the Estonian Ministry of Education and Research (project SF 0170006s08) and by the Estonian Science Foundation (grants 6820 and 7643). Hydrobiological collections of the Centre for Limnology and data of the Estonian State monitoring programme were used. We are indebted to Mrs Ester Jaigma for revising the English text of this paper. The comments of anonymous referees and editorial corrections are highly appreciated.

\section{REFERENCES}

Adrian, R. \& Deneke, R. 1996. Possible impact of mild winters on zooplankton succession in eutrophic lakes of the Atlantic European area. Freshwater Biol., 36, 757-770.

Adrian, R., Walz, N., Hintze, T., Hoeg, S. \& Rusche, R. 1999. Effects of ice duration on plankton succession during spring in a shallow polymictic lake. Freshwater Biol., 41, 621-632.

Adrian, R., Wilhelm, S. \& Gerten, D. 2006. Life-history traits of lake plankton species may govern their phenological response to climate warming. Glob. Change Biol., 12, 652-661.

Andronikova, I. N. 1996. Structural and Functional Organization of Zooplankton in Lake Ecosystems of Different Trophic Status. Nauka, St. Petersburg (in Russian). 
R. Laugaste et al.

Berger, S. A., Diehl, S., Stibor, H., Trommer, G., Ruhenstroth, M., Wild, A., Weigert, A., Jäger, C. G. $\&$ Striebel, M. 2007. Water temperature and mixing depth affect timing and magnitude of events during spring succession of the plankton. Oecologia, 150, 643-654.

Blank, K., Haberman, J., Haldna, M. \& Laugaste, R. 2009. Effect of winter conditions on spring nutrient concentrations and plankton in a large shallow Lake Peipsi (Estonia/Russia). Aquat. Ecol., 43, 745-753.

Blank, K., Laugaste, R. \& Haberman, J. 2010. Temporal and spatial variation in the zooplankton: phytoplankton biomass ratio in a large shallow lake. Estonian J. Ecol., 59, 99-115.

Chen, C. Y. \& Folt, C. L. 2002. Ecophysiological responses to warming events by two sympatric zooplankton species. J. Plankton Res., 6, 579-589.

George, D. G., Maberly, S. C. \& Hewitt, D. P. 2004. The influence of the North Atlantic Oscillation on the physical, chemical and biological characteristics of four lakes in the English Lake District. Freshwater Biol., 49, 760-774.

Gerten, D. \& Adrian, R. 2000. Climate-driven changes in spring plankton dynamics and the sensitivity of shallow polymictic lakes to North Atlantic Oscillation. Limnol. Oceanogr., 45, $1058-1066$

Gerten, D. \& Adrian, R. 2002. Effects of climate warming, North Atlantic Oscillation, and El NiñoSouthern Oscillation on thermal conditions and plankton dynamics in northern hemispheric lakes. Sci. World J., 2, 586-606.

Haberman, J. 1995. Dominant rotifers of Võrtsjärv (Estonia). Hydrobiologia, 313/314, 313-317.

Haberman, J. 2001. Zooplankton. In Lake Peipsi: Flora and Fauna (Pihu, E. \& Haberman, J., eds), pp. 50-68. Sulemees Publishers, Tartu.

Haberman, J. \& Künnap, H. 2002. Mean zooplankter weight as a characteristic feature of an aquatic ecosystem. Proc. Estonian Acad. Sci. Biol. Ecol., 51, 26-44.

Haberman, J. \& Laugaste, R. 2003. On characteristics reflecting the trophic state of large and shallow Estonian lakes (L. Peipsi, L. Võrtsjärv). Hydrobiologia, 506/509, 737-744.

Haberman, J., Virro, T. \& Krikmann, K. 2008. Zooplankton. In Peipsi (Haberman, J., Timm, T. \& Raukas, A., eds), pp. 271-290. Eesti Loodusfoto, Tartu.

Hurrell, J. W., Kushnir, Y. \& Visbeck, M. 2001. The North Atlantic Oscillation. Science, 291, 603-608.

Ibneeva, N. I. 1983. Exploitation of food resources by planktophagous fishes in Lake Peipsi-Pihkva. Sb. nauchn. tr. GosNIORKh, 209, 44-50 (in Russian).

Irigoien, X., Harris, R. P., Head, R. N. \& Harbour, D. 2000. North Atlantic Oscillation and spring bloom phytoplankton composition in the English Channel. J. Plankton Res., 22, 2367-2371.

Jaagus, J. 2003. Uusi andmeid Eesti kliimast. In Uurimusi Eesti kliimast, pp. 78-101. Publicationes Instituti Geographici Universitatis Tartuensis.

Jaagus, J. 2008. Läbi aegade kõige soojem talv. Eesti Loodus, 12, 6-13.

Jaani, A. 2001. Thermal regime and ice conditions. In Lake Peipsi: Meteorology, Hydrology, Hydrochemistry (Nõges, T., ed.), pp. 65-71. Sulemees Publishers, Tartu.

Jeppesen, E., Søndergaard, M., Jensen, J.-P., et al. 2005. Lake responses to reduced nutrient loading - an analysis of contemporary long-term data from 35 case studies. Freshwater Biol., 50, $1747-1771$

Köhler, J. \& Hoeg, S. 2000. Phytoplankton selection in a river-lake system during two decades of changing nutrient supply. Hydrobiologia, 424, 13-24.

Laugaste, R., Nõges, P., Nõges, T., Yastremskij, V. V., Milius, A. \& Ott, I. 2001. Algae. In Lake Peipsi: Flora and Fauna (Pihu, E. \& Haberman, J., eds), pp. 31-49. Sulemees Publishers, Tartu.

Leppäranta, M., Reinart, A., Erm, A., Arst, H., Hussainov, M. \& Sipelgas, L. 2003. Investigation of ice and water properties and under-ice light fields in fresh and brackish water bodies. Nord. Hydrol., 34, 245-266.

Livingstone, D. M. 1993. Temporal structure in the deep-water temperature of four Swiss lakes: a short term climate change indicator? Verh. Internat. Verein. Theor. Angew. Limnol., 25, 75-81. 
Livingstone, D. M. 2000. Large-scale climatic forcing detected in historical observations of lake ice break-up. Verh. Internat. Verein. Limnol., 27, 2775-2783.

Magnuson, J. J., Robertson, D. M., Benson, B. J., Wynne, R. H., Livingstone, D. M., Arai, T., Assel, R. A., Barry, R. G., Card, V., Kuusisto, E., Granin, N. G., Prowse, T. D., Stewart, K. M. \& Vuglinski, V. S. 2000. Historical trends in lake and river ice cover in the Northern Hemisphere. Science, 289, 1743-1746.

McKee, D., Atkinson, D., Collings, S., Eaton, J., Harvey, I., Heyes, T., Hatton, K., Wilson, D. \& Moss, B. 2002. Macro-zooplankter responses to simulated climate warming in experimental freshwater microcosms. Freshwater Biol., 47, 1557-1570.

Matveev, V. \& Matveeva, L. 1997. Grazer control and nutrient limitation of phytoplankton biomass in two Australian reservoirs. Freshwater Biol., 38, 49-65.

Mehner, T. 2000. Influence of spring warming on the predation rate of underyearling fish on Daphnia - a deterministic simulation approach. Freshwater Biol., 45, 253-263.

Milius, A. \& Haldna, M. 2008. Hüdrokeemia. In Peipsi (Haberman, J., Timm, T. \& Raukas, A., eds), pp. 157-178. Eesti Loodusfoto, Tartu.

Nõges, T. 2004. Reflection of the changes of the North Atlantic Oscillation Index and the Gulf Stream Position Index in the hydrology and phytoplankton of Võrtsjärv, a large, shallow lake in Estonia. Boreal Environ. Res., 9, 401-407.

Nõges, P. \& Kisand, A. 1999. Horizontal distribution of sediment phosphorus in shallow eutrophic lake Võrtsjärv (Estonia). Hydrobiologia, 408/409, 167-174.

OECD. 1982. Eutrophication of Water, Monitoring, Assessment and Control. Organization for Economic Cooperation and Development (O.E.C.D.), Paris.

Peeters, F., Straile, D., Lorke, A. \& Livingstone, D. M. 2007. Earlier onset of the spring phytoplankton bloom in lakes of the temperate zone in a warmer climate. Glob. Change Biol., 13, 1898-1909.

Phillips, K. A. \& Fawley, M. W. 2002. Winter phytoplankton community structure in three shallow temperate lakes during ice cover. Hydrobiologia, 470, 97-113.

Richardson, A. J. 2008. In hot water: zooplankton and climate change. J. Mar. Sci., 65, 279-295.

Rivier, I. K. 1996. Ecology of diapausing copepodids of Cyclops kolensis Lill. in reservoirs of the Upper Volga. Hydrobiologia, 320, 235-241.

Romare, P., Schindler, D. E., Scheuerell, M. D., Scheuerell, J. M., Litt, A. H. \& Shepherd, J. H. 2005. Variation in spatial and temporal gradients in zooplankton spring development: the effect of climatic factors. Freshwater Biol., 50, 1007-1021.

Rummukainen, M., Räisänen, J., Bringfelt, B., Ullerstig, A., Omstedt, A., Willén, U., Hansson, U. \& Jones, C. 2001. A regional climate model for northeastern Europe: model description and results from the downscaling of two GCM control simulations. Clim. Dynam., 17, 339-359.

Sarvala, J., Helminen, V., Saarikari, V., Salonen, S. \& Vuorio, K. 1998. Relations between planktivorous fish abundance, zooplankton and phytoplankton in three lakes of differing productivity. Hydrobiologia, 363, 81-95.

SAS Institute Inc. 1999. SAS Online Doc, version 8. SAS Institute Inc., Cary.

Scheffer, M., Straile, D., Van Nes, E. H. \& Hosper, H. 2001. Climatic warming causes regime shifts in lake food webs. Limnol. Oceanogr., 46, 1780-1783.

Shatwell, T., Köhler, J. \& Nicklisch, A. 2008. Warming promotes cold-adapted phytoplankton in temperate lakes and opens a loophole for Oscillatoriales in spring. Glob. Change Biol., 14, 2194-2200.

Sikorowa, A., Mientki, C., Chudybowa, D., Widuto, J., Zmyslowska, I. \& Sobierajska, M. 1975. Experiment on the rejuvenation of Kortowskie Lake. Preliminary results of the years 1971-1973 and some earlier results. Pol. Arch. Hydrobiol., 22, 251-269.

Sommer, U., Aberle, N., Engel, A., Hansen, T., Lengfellner, K., Sandow, M., Wohlers, J., Zöller, E. \& Riebesell, U. 2007. An indoor mesocosm system to study the effect of climate change on the late winter and spring succession of Baltic Sea phyto- and zooplankton. Oecologia, 150, 655-667. 
R. Laugaste et al.

Sorvari, S., Korhola, A. \& Thompson, R. 2002. Lake diatom response to Arctic warming in Finnish Lapland. Glob. Change Biol., 8, 171-181.

Starast, H., Milius, A., Möls, T. \& Lindpere, A. 2001. Hydrochemistry of Lake Peipsi. In Lake Peipsi: Meteorology, Hydrology, Hydrochemistry (Nõges, T., ed.), pp. 97-131. Sulemees Publishers, Tartu.

Straile, D. 2000. Meteorological forcing of plankton dynamics in a large and deep continental European lake. Oecologia, 122, 44-50.

Straile, D. 2002. North Atlantic Oscillation synchronizes food-web interactions in central European lakes. Proc. R. Soc. Lond. B., 269, 391-395.

Swadling, K. M., Pienitz, R. \& Nogrady, T. 2000. Zooplankton community composition of lakes in the Yukon and Northeast Territories (Canada): relationships to physical and chemical limnology. Hydrobiologia, 431, 211-224.

Talling, J. F. 2003. Phytoplankton-zooplankton seasonal timing and clear-water phase in some English lakes. Freshwater Biol., 48, 39-52.

Ventelä, A.-M., Saarikari, V. \& Vuorio, K. 1998. Vertical and seasonal distributions of microorganisms zooplankton and phytoplankton in a eutrophic lake. Hydrobiologia, 363, 229240.

Virro, T., Haberman, J., Haldna, M. \& Blank, K. 2009. Diversity and structure of the winter rotifer assemblage in a shallow eutrophic northern temperate Lake Võrtsjärv. Aquat. Ecol., 43, $755-764$.

Wagner, A. \& Benndorf, J. 2007. Climate-driven warming during spring destabilises a Daphnia population: a mechanistic food web approach. Oecologia, 151, 351-364.

Weisse, T., Müller, H., Pinto-Coelho, R. M., Schweizer, A., Springmann, D. \& Baldringer, G. 1990. Response of the microbial loop to the phytoplankton spring bloom in a large prealpine lake. Limnol. Oceanogr., 35, 781-794.

Weyhenmeyer, G. A. 2001. Warmer winters: are planktonic algal populations in Sweden's largest lakes affected? Ambio, 30, 565-572.

Weyhenmeyer, G. A., Blenckner, T. \& Pettersson, K. 1999. Changes of the plankton spring outburst related to the North Atlantic Oscillation. Limnol. Oceanogr., 44, 1788-1792.

Weyhenmeyer, G. A., Adrian, R., Gaedke, U., Livingstone, D. M. \& Maberly, S. C. 2002. Response of phytoplankton in European lakes to a change in the North Atlantic Oscillation. Verh. Int. Ver. Limnol., 28, 1436-1439.

Weyhenmeyer, G. A., Meili, M. \& Livingstone, D. M. 2005. Systematic differences in the trend towards earlier ice-out on Swedish lakes along a latitudinal temperature gradient. Verh. Int. Ver. Limnol., 29, 257-260.

Weyhenmeyer, G. A., Westöö, A.-K. \& Willén, E. 2008. Increasingly ice-free winters and their effects on water quality in Sweden's largest lakes. Hydrobiologia, 599, 111-118.

\title{
Külm talv versus soe talv: nende mõju Peipsi järve planktonile ja vee biogeenisisaldusele
}

\author{
Reet Laugaste, Juta Haberman ja Kätlin Blank
}

Kliima soojenemine avaldub veekogudes kõige ilmekamalt kevadel ja seda eeskätt veekogu talvel katva jääkatte kestuse kaudu. Kuna õhu soojenemise mõju veetemperatuurile ja seeläbi ka ökosüsteemile on erinev sõltuvalt iga veekogu spetsiifilistest omadustest (sügavus, vee maht, kihistuse olemasolu, geograafiline asend jne), pakkus huvi vastav uuring Peipsi järve kohta. Peipsi järv oli aastail 
Effect of winter severity on spring plankton

2005 ja 2006 jääga kaetud keskmiselt 140 päeva, 2007. aastal ligi 50 ning 2008. aastal umbes 15 päeva. See andis võimaluse võrrelda kaht mõõdukalt pikka ja külma talve kahe sooja ning lühikesega ja uurida kahe perioodi jääkatte kestuse mõju järve planktonile ning vee biogeenisisaldusele. Analüüs näitas, et järve jääst vabanemise aeg mõjutab fütoplanktonit kaudselt, biogeenide kaudu, zooplanktonit aga otseselt veetemperatuuri kaudu. Lühikese kestusega jääkattega talvedele järgnevatel kevadetel olid üldlämmastiku ja üldfosfori suhe ning samuti ränisisaldus vees oluliselt suuremad kui kevaditi pärast pika kestusega jääkatet. Pideva jääkatteta 2008. aasta aprillis oli fütoplanktonis ainuraksete ketasränivetikate puhang, pika kestusega jääkattele järgneval kuul domineeris suur niitjas Aulacoseira islandica. Üldiselt moodustavad Peipsi järves mais zooplanktoni valdavalt termofoobsed talvekeriloomad Synchaeta verrucosa ja Polyarthra dolichoptera ning järves talvituvate aerjalgsete (perekond Mesocyclops, Cyclops kolensis) juveniilsed vormid - naupliused ja kopepodiidid. Termofiilsete vesikirpude (Cladocera) arenguks on veetemperatuur mais $\left(\sim 10^{\circ} \mathrm{C}\right)$ veel madal, nende (eriti perekond Daphnia) massiline areng algab juunis veetemperatuuril keskmiselt $15^{\circ} \mathrm{C}$. Juunis moodustavad zooplanktoni biomassi termofiilsete perekondade Daphnia ja Bosmina liigid, arvukuse suurema osa aga suvekeriloomad ning aerjalgsete noorvormid. Peaaegu jääkatteta 2008. aasta talvele järgnenud maikuus oli järves zooplanktonit kaks korda rohkem kui pika kestusega jääkattega 2005. ja 2006. aasta mais. Jahedatel kevadetel võimsalt domineerinud talvekeriloomad ( $\geq 20 \%$ zooplanktoni arvukusest) $S$. verrucosa ja $P$. dolichoptera olid küll arvukad ka soojadel kevadetel, kuid ei kuulunud dominantide hulka. Ka olid soojalembesed vesikirbud (perekond Bosmina liigid) maiplanktonis esindatud arvestataval hulgal vaid soojemal kevadel, mitte aga pärast kestvat jääkatet. Soojema perioodi (2007-2008) juunis oli vesikirpude (Cladocera) ja aerjalgsete (Copepoda) biomass kaks korda suurem kui külmema perioodi (2005-2006) juunis, keriloomade (Rotatoria) oma aga kaks korda väiksem. Viimast põhjustas talvel ja varakevadel võimsalt domineerinud $S$. verrucosa ning $P$. dolichoptera kadumine planktonist neile sobimatu kõrge temperatuuri tõttu. Sooja perioodi juunis oli termofiilsete vesikirpude osa zooplanktonis $24 \%$ ja biomassis $64 \%$ ning vastavalt $11 \%$ ja $42 \%$ külma perioodi juunis. Perekond Daphnia liikide (põhiliselt D. cucullata, D. galeata) biomass oli 2007. aasta juunis neli korda ja 2008. aasta juunis kümme korda suurem kui 2005. ning 2006. aasta juunis. Zooplankteri keskmine kaal, mis näitab zooplankteri kui vetikate filtreerija võimsust, olenes otseselt kuu keskmisest veetemperatuurist ja oli suurem soojadel kevadetel. Zoo- ja fütoplanktoni biomasside suhtarv $\left(\mathrm{B}_{\mathrm{Zp}} / \mathrm{B}_{\text {Phyt }}\right)$, mida kasutatakse veekogu ökosüsteemi seisundi indikaatorina, oli oluliselt suurem kevadetel pärast sooja talve. Lühike talv põhjustab selge vee perioodi nihkumise tavapärasest juunikuust maikuusse. 